\title{
t-books: A block interface for young children's narrative construction
}

\author{
Cristina Sylla ${ }^{\mathrm{a}, *}$, Íris Susana Pires Pereira ${ }^{\mathrm{b}}$, Eva Brooks ${ }^{\mathrm{c}}$, Nelson Zagalo ${ }^{\mathrm{d}}$ \\ ${ }^{a}$ Research Centre on Child Studies (CIEC), University of Minho, Braga, Portugal \\ ${ }^{\mathrm{b}}$ Research Centre on Education (CIEd), University of Minho, Braga, Portugal \\ c Aalborg University, Aalborg, Denmark \\ ${ }^{\mathrm{d}}$ University of Aveiro, Aveiro, Portugal
}

\section{A R T I C L E I N F O}

\section{Article history:}

Received 31 January 2017

Received in revised form 28 June 2018

Accepted 6 July 2018

Available online 26 July 2018

\section{Keywords:}

Digital manipulatives

Seymour papert

Storytelling

Playful learning

Children

\begin{abstract}
A B S T R A C T
This article presents a body of work developed to focus on the development of innovative learning materials that promote young children's exploration and collaborative playful learning that have been deeply inspired by Seymour Papert. Through this contribution, we highlight how his research and published concepts have had a fundamental influence upon the development of $t$-books, a digital manipulative that aims at promoting scaffolded, collaborative and creative storytelling.
\end{abstract}

(C) 2018 Elsevier B.V. All rights reserved.

\section{Introduction}

Seymour Papert assumed Piagetian learning or learning without being taught as children's natural and spontaneous way of learning $[1 ; 7,156]$. Although accepting the idea that learning is a selfregulatory process that comes out of children's exploratory actions upon the world [2], Papert developed Piaget's constructivism into what he called constructionism. Like Piaget, Papert considered that anything is easy to learn when it can be integrated into children's previous cognitive models. However, when referring to children, Papert calls them builders (rather than simply 'knowers'), [who] "need materials to build with", and he claimed that it is when children make something new with it [materials], "play with it, build with it", that intrinsically motivated learning takes place (1993:120). Therefore, Papert put a renewed emphasis on the learner in action as well as on the learning contexts within the constructivist theory and practice.

Papert conceived 'contexts that trigger learning' as situations that are deeply engaging, immersing learners in challenges, interactions and negotiations. Besides, he envisioned artifacts as essential in such learning contexts. Like Fröbel [3], Montessori [4] and Vygotsky [5], Papert considered that objects play a major role

\footnotetext{
No author associated with this paper has disclosed any potential or pertinent conflicts which may be perceived to have impending conflict with this work. For full disclosure statements refer to https://doi.org/10.1016/j.ijcci.2018.07.002.

* Corresponding author.

E-mail addresses: cristina.sylla@ie.uminho.pt (C. Sylla), iris@ie.uminho.pt (Í.S.P. Pereira), eb@learning.aau.dk (E. Brooks), nzagalo@ua.pt (N. Zagalo).
}

in giving shape to the learners' new understandings and in the expression of such new ideas. He furthermore suggested that "knowledge can be broken up into "mind-size bites" so that "it is more communicable, more assimilable, more simply constructable" [1; 171]. Simply put, Papert believed it is fundamental to provide children with the right learning materials, empowering them to perform meaningful projects that are situated in their larger social and cultural context (1993:54). This brings us to Vygostky's socioconstructivism, in particular to the role of language and, in particular, narratives, as powerful cognitive mediation tools in children's imaginative activities [5-7].

The acknowledgment of the cognitive role of artifacts as well as of stories as cultural mediators and the possibility of developing the later through the former motivated the development of $t$ books, which stands for tangible books. $t$-books is a digital manipulative [8] that was developed to promote digital storytelling. It is comprised of a set of physical blocks representing story elements, a hardcover book and an electronic platform. The back of the book and the electronic platform have magnets on the surface to assure a stable connection between both. The electronic platform connects to a computer/tablet via USB/Bluetooth. Each page of the book has slots for placing the blocks, which also have magnets on the bottom surface to assure a good and stable contact with the platform (Fig. 1). Placing a block on the book activates and displays the corresponding digital animations on the screen/monitor of a computer or tablet. The visual narrative unfolds according to the blocks that are placed on the book.

In this paper we describe the design process of $t$-books, which included a pilot study that was carried out with a group of preschool children in order to investigate how children's storytelling 
can be supported by the creation of structured narratives through a digital manipulative. The paper is organized as follows: Section 2 focuses on children's development of narrative thinking and narrative discourse; Section 3 presents an overview of research on digital manipulatives; Section 4 describes $t$-books and Section 5 reports on the pilot study; Sections 6 and 7 discuss the results of the study with special reference to Papert's constructionism.

\section{The role of narratives in children's development and chil- dren's development of narrative thinking and discourse}

t-books addresses the development of a fundamental human cognitive and emotional ability, which is narrative thinking and discourse. Narratives are a form of human thinking [9] that is fundamental in making sense out of one's social experience and in the development of one's cognition and emotions [10,11]. As Brockmeier and Harré [12; 279] assert, "narratives are at the same time models of the world and models of the self. It is through our stories that we make ourselves as part of our world". Aligned with Schleppegrell [13], we distinguish narratives from reports. The former portray an organized unfolding of fictional events in a time (and place) that is non-coincident with the now of its telling. Reports, on the other hand, constitute a sequence of experienced personal events in which the chronological order varies according to the relevance of the experiences. Thus understood, narratives unfold within an imagined time and imagined space where almost everything is possible, thus fostering the development of imagination and creativity. Simultaneously, and due to their temporal and causal organization, narratives foster the development of mental organization. In Western cultures, the basic narrative structure or scheme is composed of setting, problematic event, reaction, a sequence of events aimed to solve the problem, final and, eventually, a moral [14-16]. Narratives begin with a stable state of affairs, which is altered by a conflicting situation that forces characters to take action in order to solve the conflict and resume (and renew) stability. This temporal organization is coded by genre conventions, which establish narrative (socially) expected meaning structure $[12,17]$. An essential aspect in the organization of narratives is the causal interrelation among the events portrayed [18,19]. During the course of the action there is always a problem that has an impact on the inner 'life' of the characters, which they have to solve, and, depending on whether the problem is solved or not, narratives can have one or several episodes. By showing children organized sets of life events in time, cause and consequence, narratives also become meaningful instruments that nourish the development of empathy, which is also a fundamental dimension in children's learning and socialization. Therefore, narratives encourage social interaction [20], providing children a "nourishing habitat for the growth of cognitive, narrative and social connectivity" [21; 8]. Yet, research has shown that the development of narrative thinking and discourse is quite challenging for children. Besides limitations imposed by the normal course of vocabulary acquisition, producing narratives seems to be hindered by other major cognitive demands imposed by narrative thinking. This is, the linguistic representation of temporal and causal organization of events which inheres meaningful and coherent narrative worlds $[15,18,19,22]$. In this context, research has called attention for children's need of structures that scaffold them in planning and creating stories [23]. $t$-books provides a sheltered framework for the development of children's narrative discourse by prompting them to create stories step by step and within a framework that is organized in time, cause and consequence.

\section{Related work on digital manipulatives: Situating $\boldsymbol{t}$-books}

Mitchel Resnick, Papert's former student and longtime collaborator, was one of the first researchers that attempted to materialize Papert's tenets by developing a series of digital manipulatives for promoting children's playful learning [8], which he named Froebel's Gifts of the 21st century [24]. Digital manipulatives, often also named Tangible User Interfaces (TUIs) [25], are materials with embedded computational properties.

\subsection{Digital manipulative interfaces}

Resnick and colleagues' early work includes a set of Programm able Bricks, titled as Crickets, which can be used to create robotic constructions that interact with one another. This work expanded into an integrated family, consisting of a set of digital manipulatives in the form of blocks, beads, balls, and badges that share the same software environment for programming, communicating and interacting with one another [8].

Since then, research investigating the potential of digital manipulatives (TUIs) has focused on various aspects. Inspired by Fröbel and Montessori, researchers have proposed a classification of digital manipulatives into two categories: Froebel-inspired Manipulatives (FiMs) that enable modeling of objects and structures of the real world; and Montessori-inspired Manipulatives (MiMs), which enable modeling of abstract concepts such as the representation of numerical proportions, and relationships between quantities [26]. According to this classification, $t$-books is a FiM as it enable modeling of 'real world situations' through narrative creation.

\subsection{Digital manipulatives for storytelling}

Research concerning the design of digital manipulatives for language development and storytelling is of special interest to this paper. Outgoing from the user's perspectives and the characteristics of TUIs, Harley and colleagues [27] conceptualized a framework for the analyses of storytelling activities using tangible user interfaces. Based on Rayon's model (2002) they differentiate between four narrative positions: external-exploratory, internalexploratory, external-ontological, and internal-ontological. The first differentiation positions the user 'inside', or 'outside' the story world, these positions can then be exploratory (the user explores the narrative reconstructing or rearranging events) or ontological (the user can change the state of the story). According to their taxonomy, the majority of systems require the user to perform exploratory actions from an external narrative position, this is, the user and his/her interactions exist outside the story world [27;63]. Concerning $t$-books we argue that the user's position can be both internal and external (depending on whether the user takes the role of a character) and ontological, as it allows the users to dive into the story world and to change the state of the story. ${ }^{1}$

Chu [29] has investigated the use of narrative TUIs for learning and reflecting about cultural practices and as a means to support sensemaking and expression in narrative creation. Horn [30] reflected on the potential of TUIs for creating shared narrative experiences where social interaction can be fostered by designing TUIs that evoke cultural forms recalling the user's cognitive and emotional resources.

Research on digital manipulatives for storytelling has also focused on the role of story-listening systems for supporting emergent literacy and its potential to encourage active use of technology [31]. Among other interfaces, Cassel carried out studies with StoryMat [31,32] and TellStory [33]. Both interfaces, are among the first digital manipulatives for storytelling. StoryMat is an open-ended

1 In this context see Sylla et al. [28]. 
environment for storytelling, where children play using stuffed toys. The stories told by the children playing on the StoryMat are recorded and stored. When a new child plays on StoryMat and tells a story, a story with a similar pattern is activated and played, which intends to inspire the child playing on StoryMat in the creation of her story. Tellstory is a symbolic physical representation of the story structure that has the form of a centipede with a body of five pieces and a head. Children can record audio into each part of the body, and listen to it by pressing a button. The pieces are independent of each other and can be sorted and rearranged in different sequences. Similar to TellStory, $t$-words (tangible words) [34] consists of a set of rectangular blocks, which can be used to mediate children's oral expression. The system enables users to record, store and play audio in each block. By snapping the blocks together, the children play the recorded audio and, by reordering the blocks the played audio sequence changes according the new order. Additionally, children can draw on the surface of the blocks. A common feature of these systems is that they stimulate children's imagination through the auditory senses. Jabberstamp [35] combines drawings with voice and sound. Children can press a special rubber stamp on their drawings to record sounds, which they can then hear by using a small trumpet. Like Jabberstamp, $t$ words also stimulates children to complete their oral narratives with drawings that they can draw on the block's surface. Further examples of digital manipulatives for storytelling that stimulate children's imagination through visual perception are Make a Riddle or TeleStory [36]. Both applications run on the Siftables platform. The cubes interact with each other when placed side-by-side triggering preloaded animations and sounds, which are displayed on a parallel HD screen.

Another recent case employs tangible interfaces and storytelling to convey programming concepts to children, as it is the case of TanProStory [37]. The interface promotes narrative creation by manipulating programming blocks in order to introduce objectoriented programming concepts to children, such as object and attribute. The Collaborative Programmable Environment for Storytelling (CPES) promotes collaborative shared storytelling following a socio-constructivist approach [23]. It allows children to program events using tangible objects (with fiducial marks) and RFID cards.

\subsection{Interactive books}

Culturally, storytelling has always been linked to paper books. A particular kind of digital manipulatives brings together the traditional book and sensor technologies, as is the case of the Electronic Popables [38]. The interface integrates thin, flexible, paper-based electronics in traditional pop-up mechanisms that trigger sound and light. Another example is the Bridging Book [39], a printed book that has embedded magnets and can be synchronized with a digital device placed side-by-side. Thumbing through the pages of the book triggers the digital content displaying it on the device and extending the printed illustrations on the pages of the book into the device's screen. TaBooGa [40] is a recent example that combines an electronic book with tangible elements. Children can read a story on a tablet and progress through the story by moving the book's main character on a physical game board. The reading task is interlaced with physical tasks (e.g., building a bridge with LEGO), which are then integrated with the story through taking pictures.

As many of the referred digital manipulatives, $t$-books also uses physical elements to inspire narrative creation, yet $t$-books extends previous work, most notably Make a Riddle or TellStory. This is done by providing children with a great variety of story elements coming from various classical narratives for children that provide opportunities for free play and narrative creation. $t$-books furthermore explores the concept of integrating physical/digital narrative elements into a book framework for guided narrative creation.

\section{4. t-books: A block interface for scaffolding children's narra- tive construction}

t-books is part of a broader study on the development of digital manipulatives for storytelling and language competencies in general $[28,41,42]$. This study included several interventions at a Portuguese pre-school in order to investigate children's narrative discourse as well as to investigate how to best design the interface. We started by carrying out semi-structured interviews with two pre-school teachers followed by a pilot study with two classes of pre-school children.

\subsection{Teacher's interviews}

Teacher's interviews were carried out in the form of informal conversations that took place at the pre-school where the study was carried. The teachers highlighted that storytelling activities, which have a central role in the pre-school program, perform two key functions, namely they foster language development and promote children's knowledge of the world. Of particular relevance for us was their description of a storytelling activity involving a set of cards with pictures of activities, objects and characters that are used as props for creating stories. The teachers reported that when using the cards to foster narrative construction, the children usually sit on the floor in a circle and each child receives a card, subsequently the teacher places the last card in the middle of the circle. To begin the story, one child (or the teacher) places his/her card next to the one in the center and posits a sentence that relates both cards, then another child continues the story until all have placed their cards in the middle. Based on this experience, the teachers suggested that the interface should best present children with elements from traditional stories (a princess, a witch, a poisoned apple, a caldron). Further, they proposed mixing elements from different stories to support the creation of new narratives (e.g., Snow white and the Three little pigs). These, they argued, would enable the children to recreate stories that they already knew, as well as to explore different story combinations, creating original narratives. The teachers also mentioned the importance of helping children to organize their stories. To support children in this task, they suggested that the interface could guide children in the construction of a story by providing prompts in key moments to assist them in the creation of logical story sequences. Further, they considered that combining a book framework with the creation of a story would be beneficial as it would (1) trigger reflection about the story; (2) prompt children to make choices and take decisions; (3) create story sequences; and (4) foster language and vocabulary development.

\subsection{Pilot study}

After the interviews, we carried out a pilot study with two classes (fifty children) of pre-schoolers aged between five and six years old. To avoid interfering with the regular pre-school activities and to prevent possible bias caused by the teachers, the sessions took place in the painting room, which is adjacent to children's main room. The children were randomly assigned by the pre-school teachers in groups of three. Only the participating children and the researcher were present. To make children feel comfortable, the researcher and the children sat at a round table in child sized chairs. After presenting herself and assuring that children felt comfortable, the researcher asked the children if they wanted to tell a story. All the children agreed to do so. Although we were aware that children's stories would be shaped by the communicative situation $[43,44]$, we wanted to investigate how creative their stories were and how children structured them. The stories were recorded and later transcribed for analyses [45]. 
The analyses of children's stories showed that they resembled more a report than a narrative, presenting time based enumerations of a sequence of events (marked by the use of and, and then, then). This confirms research considering that such kinds of reports are characteristic for this age $[15,16,18,19,22,46]$. Most of the stories were focused on the here and now of its telling, describing children's daily routines. Very often the stories were about the children's family and friends, and, except for very few, most of them took place in familiar scenarios such as home, garden, preschool, playground, sleeping room, living room or football pitch. Unsurprisingly, the narratives did not follow a traditional story line, introducing story elements and connecting them by cause and effect, thus revealing structural limitations. The following transcription from a boy who participated in the study exemplifies one such narrative: "I went to pick up my father at the airport with my mother and then I went to my father's shop and then I went home".

The analyses of children's narratives carried out in the pilot study resulted in the following design guidelines: (1) provide children with narrative elements to trigger their imagination; (2) create a framework for structuring the stories.

\subsection{The t-books' interface}

t-books was developed building on the design guidelines collected in the pilot study and the interviewing of teachers. The study was further informed by previous research that has highlighted that the use of props can support children in structuring their stories [47; 154] [21]. t-books is a variation of TOK (Touch, Organize, Create), a learning environment for the construction of narratives based on the manipulation of blocks [28]. Although both interfaces target language and narrative development, each follows a different approach. While TOK acts as a playground [48] for language exploration and narrative creation, $t$-books scaffolds narrative construction.

\subsubsection{Description of the system}

t-books (tangible books) acts as a framework for guided narrative construction based on the manipulation of sequences of blocks.

The physical blocks represent scenarios, characters and objects from classical stories for children - basically, heroes and opponents [49,50]. There are five blocks representing different locations to situate the stories (Fig. 2 - top); a set of special blocks such as a cloud, which blows a strong wind, a moon that turns the day into night; as well as some "magic" blocks like a caldron or a flowerpot that can be used to knock down bad characters, or a poisoned apple and a carrot that increase the character's health (Fig. 2 bottom right).

\subsubsection{Relations between the story elements}

In $t$-books, the interactions between the story elements were modeled using behavior trees (BTs) according to traditional story plots. Each category of blocks (settings, characters, objects and nature elements) has its own BT, which defines its behavior as well as its interactions with the other categories. The characters are classified into good (princess, old man, three little pigs, fairy, Zorro) and bad (wolf, witch). As in traditional stories, the bad characters attack the good ones when they are brought together in the story world (e.g., Fig. 3, center and right); the good characters defend and help each other. Both good and bad characters can join forces to defend or attack their opponents.

Each character has a given 'health' that decreases when it fights against other characters, or increases by eating a 'magic carrot'. For instance, after a fight, the health of the involved characters always diminishes, thus giving the good characters a chance to defeat the bad characters (e.g., Fig. 3, left). This also brings a certain degree of unpredictability and surprise in the unfolding of the story (at the same time offering a certain control over the characters), allowing users to create different plots and stories.

\subsection{Creating Stories with $t$-books}

$t$-books acts as a generic frame that guides the children through the creation of their stories, scaffolding them to organize and structure their thoughts. The first page of the book has a slot for inserting a block and thus beginning story creation. The number of slots increases gradually to a total of six on the last page. Thus, when thumbing through the pages, the children are guided step by step in the construction of the narrative (see Fig. 4). To create stories, the children manipulate the blocks, placing them on $t$ books, and their story is accordingly displayed on the computer screen. Following the same principle, when a block is removed from $t$-books, it disappears from screen . Apart from the ambient sounds, $t$-books only displays visual content, which leaves space for the children to create their own spoken narratives (which they do while placing the narrative blocks on $t$-books).

In order to scaffold the creation of original narratives, each page of the book has a general story sentence written on the top of each page, such as:

$1^{\text {st }}$ Page: "Once upon a time, there was a place far, far away" [one slot]

$2^{\text {nd }}$ Page: "Oh such a wonderful place, I wonder who lives there!" [two slots]

$3^{\text {rd }}$ Page: "What are they doing?" [three slots]

$4^{\text {th }}$ Page: "What happened then?" [four slots] \} Problem/Reaction

$5^{\text {th }}$ Page: "How does the story end?" [five slots] $\}$ Resolution and End

$6^{\text {th }}$ Page: "And now, would you like to tell another story?" [six slots]

Z invitation for new story.

The text helps children to be situated in a fictional world, thus sparking their imagination, inviting them to explore and create a narrative, while leaving space for creativity.

\section{User Study}

After the development of the digital manipulative, an intervention study was conducted in which the children were requested to create stories using $t$-books. The study aimed at investigating $t$-books' potential to scaffold children in the construction of structured stories, and whether the narrative elements would promote the creation of original stories. A qualitative and inductive approach was applied to the analyses, where data collection was carried out through observations, field notes, and video recordings. A video camera was discreetly placed behind the children, who were informed about the camera, however, the analysis informed that they did not pay any further attention to it.

\subsection{Participants}

The same pre-school and the teachers that took part in the pilot study volunteered fourteen children of the same age. These were again randomly assigned by the teachers. As in the pilot study, the painting room was again used for the same reasons as pointed out in Section 4.2 .

\subsection{Apparatus and procedure}

The children were assigned into four groups of three and one group of two. One group at a time came to the room and sat at one table with the $t$-books interface. Each session lasted approximately $30 \mathrm{~min}$. The researcher ensured that the children felt comfortable and informed them that they could leave the room when they wanted. She started by showing the functioning of $t$-books and explained that they could create a story by placing blocks on the slots of the book. After assuring that the children had understood the 

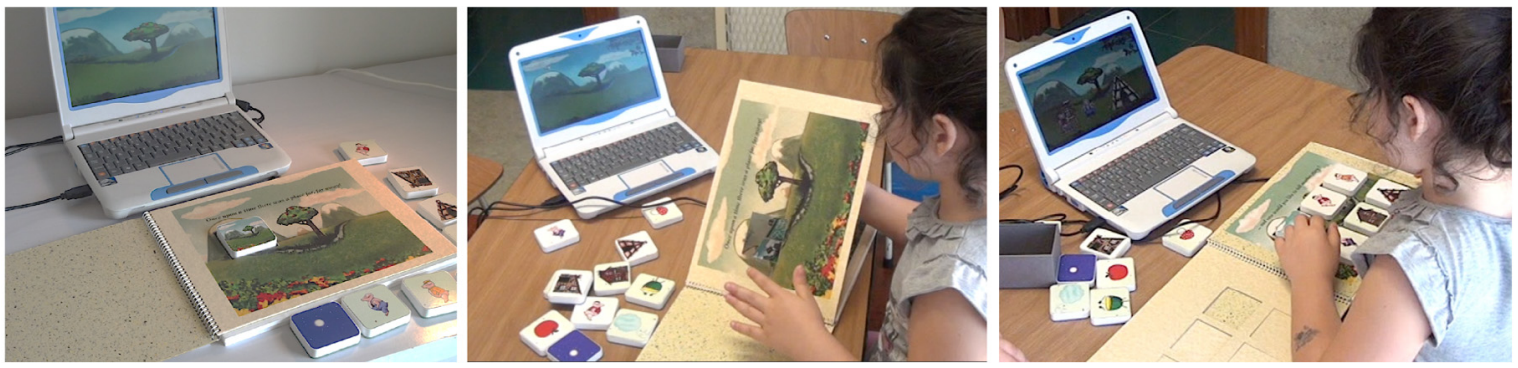

Fig. 1. $t$-book's first page (left); a girl turning the page (center); finishing a story (right).

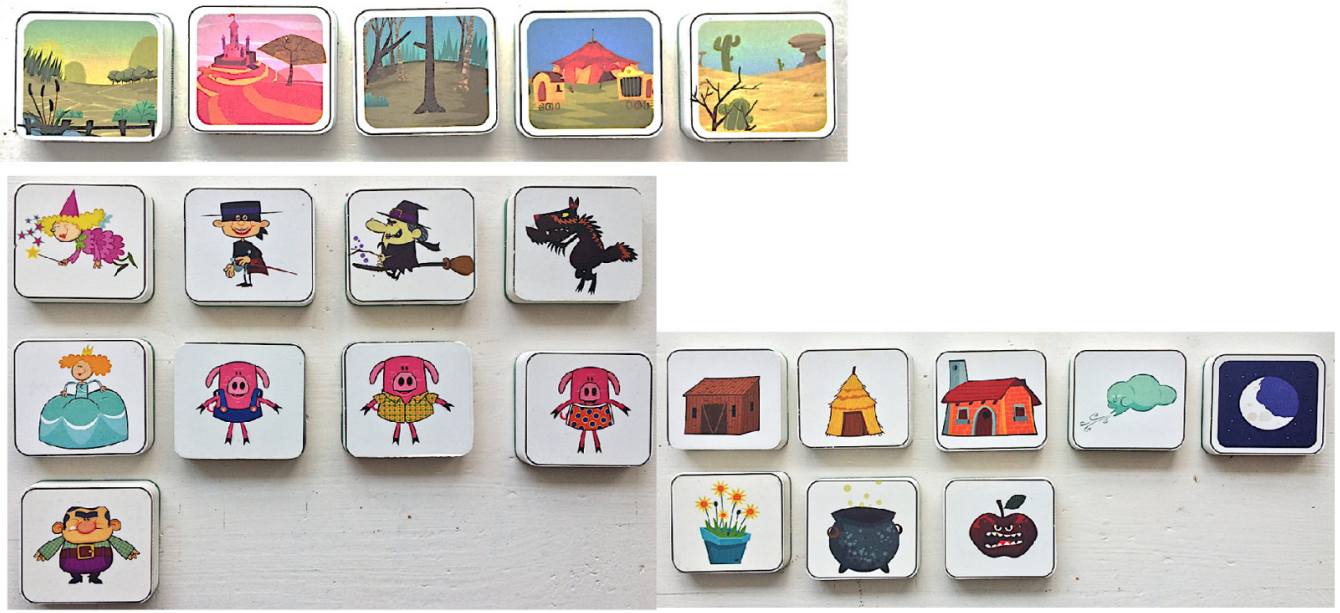

Fig. 2. $t$-books' blocks grouped in three categories: scenarios (top), objects and nature elements (bottom left), characters (bottom right)
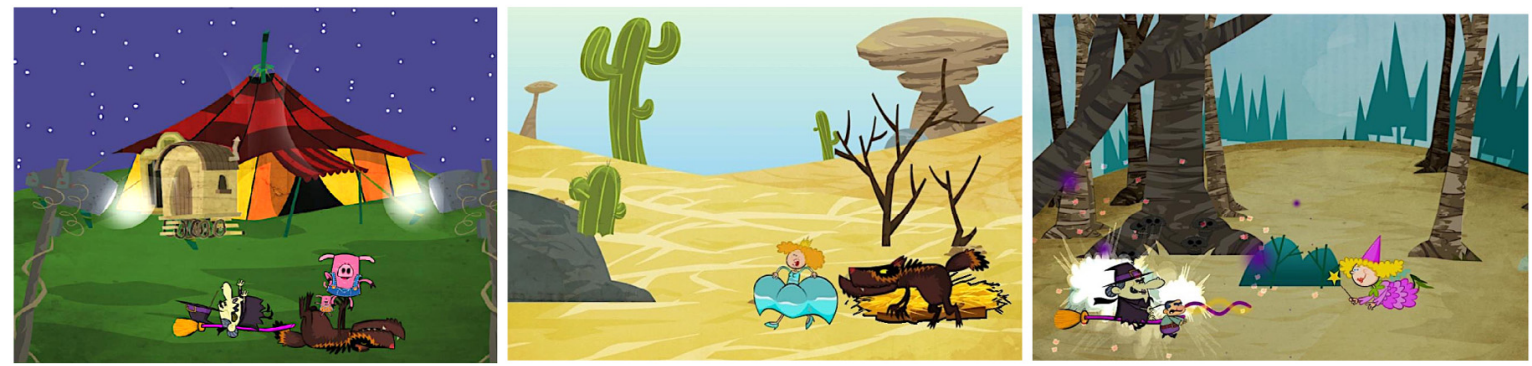

Fig. 3. The witch shrunk one pig but together the two pigs defeated the witch and the wolf (left); the wolf runs after the princess after blowing the hut away where she hid (center); The fairy helps the old man (right).
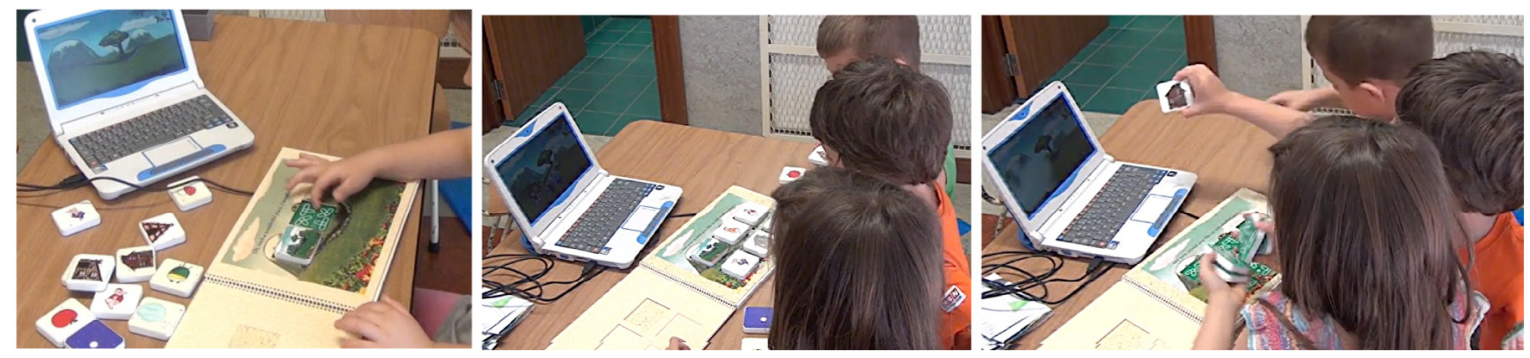

Fig. 4. A child creating a story on page 2 (left); children finishing a story (center); removing the blocks and preparing to start a new story (right).

principle behind the book, some time was allocated for exploration, during which the children could freely explore the interactions between the different narrative elements. Since these children could not yet read, the researcher read the text aloud, while the children placed the blocks on the book creating different stories.

\section{Analyses}

A thematic analysis of the video-observations showed that the children quickly understood the principle behind $t$-books. The analysis identified three main themes in children's interaction with 
the interface, namely (1) curiosity and skilfulness regarding the technical aspects of the system; (2) enjoyment in manipulating the narrative blocks and the pages of the book to create stories 'page by page'; (3) collaboration among children. These themes, detailing how the children interacted with and created narratives with the $t$-books framework, are further elaborated in the following:

(1) The children curiously explored the technical aspects of the system. They asked questions about its functioning and enjoyed turning the pages of the book as well as feeling the snapping of the blocks when they placed them on the platform. The children were curious about the blocks, they turned them on their hands and observed that the blocks had magnets on the bottom to connect to the platform. Besides, they quickly revealed skilfulness in its use. This became evident in the way the children interacted with the manipulative to create stories (see below) but also when they proudly explained to each other and to the researcher some of the tool's functionalities, which they themselves discovered e.g., "Look at this, there are two things that kill the witch: first she goes and I place this [flowerpot- block] and she dies, then [he lifts the block with the witch making her come to life on the screen again] I place the caldron and it hits her again". The mastering of the technology reinforced children's agency contributing to their engagement in the creation of their stories.

(2) The children enjoyed manipulating the narrative blocks and the pages of the book creating stories 'page by page'. All the children successfully built original narratives and were identified as enjoying the activity, as many of them wanted to create more than just one story. By following the book, the children were able to create fictional stories comprising setting, problem, reaction/ resolution and final. The following transcription exemplifies one such token:

"Many millions of years ago, there was once a little pig walking in a haunted forest, when a terrifying wolf appeared. The little pig was so scared that he fainted. Suddenly a wicked witch appeared. She was green and had a wart on her nose. It became night and it was very dark. The little pig woke up and hid in a wooden house, but the witch and the wolf attacked him and the wolf blew the house away. The little pig tried to escape but was so scared that it fainted again. It became dawn and the witch disappeared, because witches only appear at night. Suddenly two little pigs that were friends of the little pig appeared and they defeated the wolf. The three little pigs were so happy that they had a party!"

In this particular instance, it is evident that the children begin by locating their story [a haunted forest], then introducing the characters [a little pig], the problem [a terrifying wolf appeared] and the character's reaction [little pig fainted]. The children then intensify the problem by introducing a second 'bad' character [a wicked witch], then they continue the story with an attempt to resolve the problem [two little pigs appeared and defeated the wolf] and they close the story with an happy end [they had a party]. The children also change the time of the story [it became night] and resolve the conflict with an original solution [the two pigs defeated the wolf]. Within the existent framework, the children creatively developed their narrative, building on their knowledge of other stories (e.g. a witch, pigs, and a wolf) and actions [the pig hid in a wooden house, but the witch and the wolf attacked it and the wolf blew the house away]. The resulting narrative is coherent and the sentences are well connected with each other. The language is rich by using adjectives to characterize the characters and the setting, e.g., haunted forest, terrifying wolf, a wicked witch that was green and had a wart on her nose, or a wooden house. During narrative construction, the children developed meta-narrative thinking as they had to adapt their stories to the given framework.

(3) The children collaborated and coached each other along the interaction, exploring the relations between the different story elements, e.g., "don't place the cloud or it will blow everything away", or "if two pigs are together they will kill the wolf". They sometimes gave instructions/suggestions on how to place the blocks when they were not detected by the system, e.g., "you need to turn the block the other way around". The collaboration generated and supported by the narrative blocks and the book was also visible in the way the children handled the book by taking turns to handle the pages and to place the blocks. The handling of the blocks triggered various interactions and verbalizations among the children: They did not just leave the blocks on the table so that all blocks were available for all; instead, our evidence shows that they preferred having specific blocks, thus (a) the children often distributed the blocks among themselves in advance by choosing their favorites, which sometimes had to be negotiated; (b) they discussed and negotiated which block to choose to continue the stories under construction; and (c) they negotiated about who should start the story.

Through observations it was evident that $t$-books was intuitive to use and that the manipulative framework provided by the book scaffolded collaborative creation of structured yet original, creative stories.

\section{Discussion}

One of Papert's main tenets is the notion that children need materials to build with. These materials empower them to make "something new with it, play with it, build with it" and learn (1993:120) however, the lack of appropriate materials makes this difficult to achieve. This notion is well supported by the empirical findings presented herein. In this research, we observed how restricted children's narrative capacity was in the pilot study, when no scaffolding was provided. Differently, we have shown how original and creative their stories became when scaffolded by $t$ books. The children were enthusiastic about $t$-books and related to it in a very personal way, engaging and playing with the materials. In fact, the materials (building blocks) promoted active and collaborative story construction. In accordance with Papert's notion that by decomposing the task into mind-size bites makes leaning more assimilable, the segmentation of the story into small narrative units scaffolded the creation of structured narratives, making the task "more communicable, more assimilable, more simply constructable" $[1 ; 171]$. Starting from narrative elements from well known stories, the children were able to appropriate and transform the elements creating original narratives. The stories were fully shaped by children's exploration of the materials and its possibilities. The collaborative manipulation of the materials increased the children's involvement as they mutually inspired (and scaffolded) each other, building on each other's ideas, immersing in challenges, interactions and negotiations. This illustrates Papert's conception of learning contexts, where children became learners in action, showing how, as defended by Papert, artifacts scaffold learners in overcoming challenges. In the process of constructing their narratives, the children reflected over the task, activating their meta-narrative thinking, which suggests that the materials acted as objects to think with [51]. Bearing in mind the relevance of storytelling as cognitive tools that mediate children's imagination and the development of the organized thought and emotions ( $\mathrm{Vy}$ gotsky, 1997; [6,7], there is seemingly relevant learning achievements attainable through the use of $t$-books.

In Remembering Seymour Papert, Sheryl Turkel [51] explains in few words Pappert's learning Philosophy and the importance of objects: "For his legacy was not only in how children learn in classrooms and out of them. It is in using objects to help people think about how they know what they know. A focus on objects brings philosophy into everyday life". 


\section{Conclusion}

This article presents an investigation carried out with $t$-books, a physically contextualized learning environment that supports hands-on learning. The investigation consisted of (1) a pilot (design) study with a randomly assigned sample of 50 children from two classes of a Portuguese pre-school, (2) interviews with the children's teachers, and (3) a further (narrative creation/artifact testing) study consisting of fourteen randomly assigned different students from the same pre-school. The design of $t$-books was informed by Seymour Papert's constructionist vision of learning, placing the learner in action in a constructivist learning context that is supported by active learning materials. Children were scaffolded through $t$-books in the construction of structured narratives, which also triggered their imagination. The user study presented in this article contributes to the understanding of the learning role played by digital manipulatives. In Papert's sense, $t$-books became the materials to build with and the children became the builders of their stories. In future work, we will investigate how a model of 'narrative-doing' is assimilated/used by the children alongside the pedagogical use of $t$-books in the context of primary schools. An additional focus of future studies is to investigate how children's creation of narratives unfolds as collaboration over the course of storytelling sessions.

\section{Acknowledgments}

We thank the children and the teachers from Colégio Teresiano in Braga for their participation in this study. We thank the reviewers of this paper for their insightful and constructive comments that have strongly contributed to improve the paper. This work has been supported by the Portuguese Foundation for Science and Technology - FCT grant: SFRH/BPD/111891/2015, and by European funds, Reference: POCI-01-0145-FEDER-032580.

\section{References}

[1] S. Papert, Mindstorms: Children, Computers, and Powerful Ideas, second ed., Harvester, Wheatsheaf, New York, 1993.

[2] J. Piaget, The Development of Thought: Equilibrium of Cognitive Structures, Viking Press, NewYork, NY, 1977.

[3] F. Fröbel, Pedagogics of the Kindergarten, D. Appleton and Company, New York, NY, 1909.

[4] M. Montessori, The Advanced Montessori Method, R. Bentley, Cambridge, Mass., 1964.

[5] L.S. Vygotsky, Play and its role in the mental development of the child, in: M. Cole (Ed.), Soviet Developmental Psychology: An Anthology, 1977, pp. 76-99.

[6] K. Egan, Imagination in Teaching and Learning, University of Chicago, Chicago, 1992.

[7] N. Gajdamaschko, Theoretical concerns. Vygotsky on imagination development, Educ. Perspect. 39 (2) (2006) 34-40.

[8] M. Resnick, F. Martin, R. Berg, R. Borovoy, V. Colella, K. Kramer, B. Silverman, Digital manipulatives: new toys to think with, in: Proceedings of the Conference on Human Factors in Computing Systems, ACM Press, New York, NY, 1998, pp. 281-287.

[9] J.S. Bruner, The narrative construction of reality, Crit. Inquiry 8(1)(1991) 1-21. http://dx.doi.org/10.1086/448619. (Retrieved January 2018).

[10] J.S. Bruner, H. Haste (Eds.), Making Sense: The Child'S Construction of the World, Methuen, London, 1987.

[11] S. Eagle, Learning in the early years: social interactions around picturebooks, puzzles and digital technologies, Comput. Edu. 59 (1)(2011) 38-49.

[12] J. Brockmeier, R. Harré, Narrative: Problems and promises of an alternative paradigm, Res. Lang. Soc. Interact. 30 (4) (1997) 263-283.

[13] M.J. Schleppegrell, The Language of Schooling: A Functional Linguistics Perspective, Erlbaum, Mahwah, NJ, 2004.

[14] W. Labov, J. Waletzky, Narrative analyses: Oral versions of personal experience, in: J. Helm (Ed.), Essays on the Verbal and Visual Arts, University of Washington Press, Seattle, 1967, pp. 12-44.

[15] O.C. Sousa, Emergência e desenvolvimento de relações de causalidade em narrativas de crianças, Filol. Linguíst. Port. 12 (1) (2010) 91-104.

[16] O.C. Sousa, M.E. Silva, A produção de texto narrativo no 10 Ciclo: detecção de alguns problemas, in: A. Bárrios, J. Ribeiro (Eds.), Actas do II Encontro Nacional de Investigação e Formação, CIED, Lisboa, 2003, pp. 181-192.
[17] L.A. Marcuschi, Gêneros textuais: definição e funcionalidade, in: A.P. Dionisio, et al. (Eds.), Gêneros textuais \& ensino, Lucerna, Rio de Janeiro, 2002, pp. 19-36.

[18] G. Pinto, C. Tarchi, L. Bigozzi, The relationship between oral and written narratives: A three-year longitudinal study of narrative cohesion, coherence, and structure, Br. J. Educ. Psychol. 85 (4) (2015) 551-569. http://dx.doi.org/10. 1111/bjep.12091.

[19] G. Pinto, C. Tarchi, L. Bigozzi, Development in narrative competences from oral to written stories in five-to seven-year-old children, Early Child. Res. Q. 36 (2016) 1-10. http://dx.doi.org/10.1016/j.ecresq.2015.12.001.

[20] K.M. Speaker, D. Taylor, R. Kamen, Storytelling: Enhancing language acquisition in young children, Education 125 (1) (2004) 3-14.

[21] V.G.A. Paley, Child'S Work: The Importance of Fantasy Play, Chicago University Press, Chicago, 2004.

[22] R.A. Berman, D.I. Slobin, (1994) Introduction, in: R. A. Berman, D.I. Slobin (Orgs.), Relating events in narrative: A crosslinguistic developmental study, Lawrence Erlbaum, Hillsdale, NJ, 1994, pp. 1-38.

[23] M.C. Baranauskas, J.E. Posada, Tangible and shared storytelling: Searching for the social dimension of constructionism, in: Proceedings of the IDC International Conference on Interaction Design and Children, ACM Press, New York, NY, 2017, pp. 193-203. http://dx.doi.org/10.1145/3078072.3079743.

[24] M. Resnick, All I Really Need to Know (About Creative Thinking) I Learned (By Studying How Children Learn) in Kindergarten, in: Proceedings of the 6th ACM SIGCHI Conference on Creativity \& Cognition, ACM Press, Washington, DC, USA, 2007, pp. 1-6.

[25] H. Ishii, B. Hullmer, Tangible bits: Towards seamless interfaces between people, bits and atoms, in: Proceedings of the Conference on Human Factors in Computing Systems, ACM Press, New York, NY, 1997, pp. 434-441.

[26] O. Zuckerman, S. Arida, M. Resnick, Extending tangible interfaces for education: Digital Montessori-inspired manipulatives, in: Proceedings of the Conference on Human Factors in Computing Systems, ACM Press, New York, NY, 2005, pp. 859-868.

[27] D. Harley, J.H. Chu, J. Kwan, A. Mazalek, Towards a framework for tangible narratives, in: Proceedings of the 10th International Conference on Tangible, Embedded, and Embodied Interaction, TEI '16, ACM Press, NY, New York, NY, 2016.

[28] C. Sylla, C. Coutinho, P. Branco, A digital manipulative for embodied "stagenarrative" creation, Entertain. Comput. 5 (4) (2014) 495-507. http://dx.doi. org/10.1016/j.entcom.2014.08.011.

[29] J.H. Chu, Designing tangible interfaces to support expression and sensemaking in interactive narratives, in: Proceeding of the 9th International Conference on Tangible, Embedded, and Embodied Interaction, TEI'15, ACM Press, NY, New York, NY, 2015, pp. 457-460.

[30] M.S. Horn, The role of cultural forms in tangible interaction design, in: Proceedings of the 7th International Conference on Tangible, Embedded and Embodied Interaction, New York: ACM Press, 2013, pp. 117-124.

[31] J. Cassel, Towards a model of technology and literacy development: Story listening systems, J. Appl. Dev. Psychol. 25 (2004) 75-105.

[32] J. Cassell, K. Ryokai, Making space for voice: Technologies to support children's fantasy and storytelling, J. Pers. Technol. 5 (3) (2001) 203-224.

[33] M. Ananny, Telling tales: A new toy for encouraging written literacy through oral storytelling, in: Proceedings of the Biennale Conference Society for Research in Child Development, Minneapolis, 2001.

[34] C. Sylla, S. Gonçalves, P. Branco, C. Coutinho, Peter piper picked a peck of pickled peppers - an interface for playful language exploration, in: Proceedings of the ACM International Conference on Human Factors in Computing Systems, CHI '13, in: Extended Abstracts, ACM Press, New York, NY, 2013, pp. 31273130. http://dx.doi.org/10.1145/2468356.2479627.

[35] H. Raffle, C. Vaucelle, R. Wang, H. Ishii, Jabberstamp: embedding sound and voice in traditional drawings, in: Proceedings of the International Conference on Computer Graphics and Interactive, ACM Press, New York, NY, 2007, pp. 137-144.

[36] S. Hunter, J. Kalanithi, D. Merrill, Make a riddle and telestory: Designing children's applications for the siftables platform, in: Proceedings of the 9th IDC International Conference on Interaction Design and Children, ACM Press, New York, NY, 2010, pp. 206-209.

[37] Y. Qi, D. Wang, L. Zhang, Y. Shi, TanProStory: A tangible programming system for children's storytelling, in: Proceedings of CHI Extended Abstracts, ACM Press, New York, NY, 2015, pp. 1001-1006.

[38] J. Qi, L. Buechley, Electronic popables: Exploring paper-based computing through an interactive pop-up book, in: Proceedings of the 4th International Conference on Tangible, Embedded, and Embodied Interaction, ACM Press, New York, NY, 2010, pp. 121-128.

[39] A.C. Figueiredo, A.L. Pinto, P. Branco, N. Zagalo, M.E. Coquet, Bridging book: a not-so-electronic children's picture book, in: Proceedings of the 12th International Conference on Interaction Design and Children, ACM Press, New York, NY, 2013, pp. 569-572.

[40] R. Linke, T. Kothe, F. Alt, TaBooGa - A hybrid learning app to support children's reading motivation, in: Proceedings of the International Conference on Interaction Design and Children, ACM Press, New York, NY, 2017, pp. 278-285. 
[41] C. Sylla, C. Coutinho, P. Branco, W. Müller, Investigating the use of digital manipulatives for storytelling in pre-school, Int. J. Child-Comput. Interact. (2015) 39-48.

[42] C. Sylla, I.S.P. Pereira, C. Coutinho, P. Branco, Digital manipulatives as scaffolds for pre-schoolers' language development, IEEE Trans. Emerg. Top. Comput. (2016).

[43] M. Silva, A. Spinillo, A Influência de Diferentes Situações de Produção na Escrita de Histórias, Psicol. Reflexão e Crítica 13 (3) (2000) 337-350.

[44] M. Cárnio, J. Casemiro, K. Ribeiro, A. Soares, Estímulos Visuais e Produção Escrita de Escolares com e sem Queixas de Alterações na Escrita, Psicol. Reflexão e Crítica 26 (3) (2013) 516-523.

[45] C. Sylla, S. Gonçalves, P. Brito, P. Branco, C. Coutinho, t-books - merging traditional storybooks with electronics, in: Proceedings of the International Conference on Interaction Design and Children, ACM Press, New York, NY, 2012, pp. 323-326. http://dx.doi.org/10.1145/2307096.2307157.

[46] O.C. Sousa, Desenvolvimento da competência narrativa, in: O. Sousa, A. Cardoso (Eds.), Desenvolver competências em Língua Portuguesa, CIED, Lisboa, 2008, pp. 13-52.
[47] J. Van Scoter, The potential of IT to foster literacy development in kindergarten, in: J. Voogt, G. Knezek (Eds.), International HandBook of Information Technology in Primary and Secondary Education, Part One, Springer, London, 2008, pp. 149-161.

[48] E. Ackermann, Constructing knowledge and transforming the world, in: $\mathrm{M}$. Tokoro, L. Steels (Eds.), A Learning Zone of One'S Own: Sharing Representations and Flow in Collaborative Learning Environments, IOS Press, Amsterdam, Berlin, Oxford, Tokyo, Washington, DC, 2004, pp. 15-37. Part 1, Chapt 2.

[49] A.J. Greimas, Actants, actors, and figures. On meaning: Selected writings in semiotic theory, in: Theory and History of Literature, vol. 38, U. of Minnesota P., Minneapolis, 1973, pp. 106-120. Trans. Paul J. Perron and Frank H. Collins, 1987.

[50] V. Propp, Morphology of the Folktale, second ed., in: Trans. Laurence Scott., University of Texas Press, Austin, 1928-1968.

[51] S. Turkel, Remembering Seymour Papert, 2017. https://www.lrb.co.uk/blog/ 2017/02/24/sherry-turkle/remembering-seymour-papert/. (Retrieved Janu ary 2018). 